\title{
Spruce sugars and poultry hydrolysate as growth medium in repeated fed-batch fermentation processes for production of yeast biomass
}

\author{
David Lapeña ${ }^{1} \cdot$ Pernille M. Olsen ${ }^{1} \cdot$ Magnus $\emptyset$. Arntzen ${ }^{1} \cdot$ Gergely Kosa $^{1} \cdot$ Volkmar Passoth $^{2} \cdot$ Vincent G. H. Eijsink $^{1}$. \\ Svein J. Horn ${ }^{1}$ (D)
}

Received: 17 September 2019 / Accepted: 13 December 2019 / Published online: 27 December 2019

(c) The Author(s) 2019

\begin{abstract}
The production of microbial protein in the form of yeast grown on lignocellulosic sugars and nitrogen-rich industrial residues is an attractive approach for reducing dependency on animal and plant protein. Growth media composed of enzymatically saccharified sulfite-pulped spruce wood, enzymatic hydrolysates of poultry by-products and urea were used for the production of single-cell protein. Strains of three different yeast species, Cyberlindnera jadinii, Wickerhamomyces anomalus and Blastobotrys adeninivorans, were cultivated aerobically using repeated fed-batch fermentation up to $25 \mathrm{~L}$ scale. Wickerhamomyces anomalus was the most efficient yeast with yields of $0.6 \mathrm{~g}$ of cell dry weight and $0.3 \mathrm{~g}$ of protein per gram of glucose, with cell and protein productivities of $3.92 \mathrm{~g} / \mathrm{L} / \mathrm{h}$ and $1.87 \mathrm{~g} / \mathrm{L} / \mathrm{h}$, respectively. Using the conditions developed here for producing W. anomalus, it would take 25 industrial $\left(200 \mathrm{~m}^{3}\right)$ continuously operated fermenters to replace $10 \%$ of the fish feed protein used in Norway.
\end{abstract}

Keywords Protein hydrolysate $\cdot$ Single-cell protein $\cdot$ Aquaculture $\cdot$ Downstream processing $\cdot$ Repeated batch

$\begin{array}{ll}\text { Abbreviations } \\ \text { SCP } & \text { Single-cell protein } \\ \text { YP } & \text { Yeast extract and meat peptone } \\ \text { CDW } & \text { Cell dry weight } \\ \text { HPLC } & \text { High-performance liquid chromatography } \\ \text { ICS } & \text { Ion chromatography system } \\ \text { ICP-MS } & \text { Inductively coupled plasma mass spectrometry } \\ \text { AA } & \text { Amino acid } \\ \text { EAA } & \text { Essential amino acid } \\ \text { NEAA } & \text { Non-essential amino acid } \\ Y_{\mathrm{X} / \text { sugars }} & \text { Yield, g dry yeast per g sugar fed }(\mathrm{g} / \mathrm{g}) \\ Y_{\mathrm{P} / \text { sugars }} & \text { Yield, g yeast protein per g sugar fed }(\mathrm{g} / \mathrm{g}) \\ Y_{\mathrm{X} / \mathrm{glucose}} & \text { Yield, g dry yeast per } \mathrm{g} \text { consumed glucose }(\mathrm{g} / \mathrm{g})\end{array}$

Electronic supplementary material The online version of this article (https://doi.org/10.1007/s00449-019-02271-x) contains supplementary material, which is available to authorized users.

Svein J. Horn

svein.horn@nmbu.no

1 Faculty of Chemistry, Biotechnology and Food Science, Norwegian University of Life Sciences, P.O. Box 5003, N-1432 Ås, Norway

2 Department of Molecular Sciences, Swedish University of Agricultural Sciences, P.O. Box 7015, S-75007 Uppsala, Sweden
$Y_{\mathrm{P} / \text { glucose }} \quad$ Yield, g yeast protein per g consumed glucose (g/g)
$Q_{x} \quad$ Productivity, g dry yeast per liter and hour (g/L/h)
$Q_{p} \quad$ Productivity, g yeast protein per liter and hour $(\mathrm{g} / \mathrm{L} / \mathrm{h})$

\section{Introduction}

A possible future shortage of feed protein will force mankind to explore alternative protein sources that could replace conventional soymeal or fish meal [1]. Several large industrial organic side-streams could potentially be upgraded to feed protein using fermentation processes [2, 3]. Single-cell protein (SCP) refers to cells of microorganisms such as algae, fungi or bacteria which are produced in bioreactors and then used as a protein source in human food or animal feed. Yeast is the most widely accepted microorganism for SCP production [4], because of its superior nutritional quality and acceptability among consumers [5]. Generally, yeast consists of $45-55 \%$ (w/w) protein [6], has a beneficial amino-acid profile according to FAO guidelines [7], and is a good source of vitamins [8]. Furthermore, yeast cell walls contain different proportions of mannan-oligosaccharides, $\beta$-glucan, and 
chitin [9] with potential health-promoting effects [10], such as stimulation of the immune and antioxidant systems in fish [11]. Yeast can be used as whole cell preparations, or the cell wall might be partly broken down to make the protein and the cell wall components more accessible, using mechanical force, hydrolytic enzymes or detergents [7].

A wide variety of substrates have been utilized to cultivate different microorganisms, but to achieve large-scale production and to reduce the cost of SCP, relatively cheap agroindustrial by-products need to be considered as growth medium ingredients [3]. Yeasts can utilize by-products from agriculture, forestry (lignocellulosic residues) and food industries (hydrolysates from meat and fish by-products) as carbon and nitrogen sources for single-cell protein production $[12,13]$. Nitrogen might also be sourced from a combination of protein hydrolysates and inorganic nitrogen such as ammonium salts, nitrates and urea, which are relatively cheap nitrogen sources [14]. Yeasts can utilize various inorganic nitrogen compounds as a sole source of nitrogen [15].

In general, fermentation processes can be classified into batch, fed-batch and continuous fermentations. The chosen mode of operation is to a large extent dictated by the kind of products one is aiming for and process economy. A batch fermentation is a closed culture system that contains a finite amount of nutrients that will be consumed after a relatively short period of time, and is thus not ideal for the purpose of SCP production [16]. Fed-batch fermentations are initially established in batch mode and then continuously, or sequentially, fed with fresh medium without removal of culture [17], but have not been established for the production of SCP at a large industrial scale [18]. During continuous fermentations, fresh medium is constantly fed into the fermenters at a constant rate while used media containing microbes are continuously harvested. Therefore, medium conditions do not change over time, and the same growth rate can be maintained throughout the whole cultivation [19]. Continuous fermentation has been the preferred strategy to produce SCP industrially [20, 21]. Another good strategy is called repeated fed-batch fermentation, which is a semi-continuous system of operation where a portion of culture is harvested at regular intervals and replaced by an equal volume of fresh medium [22]. It is considered as one of the best fermentation set-ups for economical SCP production [23]. In contrast to batch fermentation, production of biomass can in this case be prolonged over time, while low dissolved oxygen levels due to the increase of microbial biomass are avoided since cells are withdrawn and replaced with fresh medium. Compared to continuous fermentation, the harvested culture can potentially have a higher concentration of microbial biomass, which can improve the efficiency of the downstream processing.

In this study, media composed of sugars from enzymatically hydrolysed lignocellulosic biomass [24], enzymatically hydrolyzed poultry by-products [13] and urea were used to produce SCP in a semi-continuous mode (repeated fedbatch fermentation). Three different yeast strains belonging to the species Cyberlindnera jadinii (anamorph name Candida utilis), Wickerhamomyces anomalus and Blastobotrys adeninivorans (synonym Arxula adeninivorans) were tested. Repeated fed-batch fermentations at $1.5 \mathrm{~L}$ scale were carried out using benchtop fermenters, where concentrations of cells, substrates, side products and yeast protein were monitored. Production of the best-performing yeast strain, W. anomalus $\mathrm{J} 121$, was scaled up to $25 \mathrm{~L}$, and the resulting yeast biomass was analyzed for protein and amino-acid content. Finally, the effect of several cell disruptive methods on the yeast morphology was investigated using autolysis, exogenous enzymes and mechanical force.

\section{Materials and methods}

\section{Materials}

Protein-rich enzymatic hydrolysates from chicken and turkey cut-offs were provided by BIOCO AS (Hærland, Norway) and were kept at $4{ }^{\circ} \mathrm{C}$ until further use. The poultry hydrolysates contained $50.37 \pm 0.03 \%$ dry matter out of which $88 \%$ was protein, according to product specifications. Glucose was purchased from VWR chemicals (Radnor, United States), and xylose, mannose, lactic acid, acetic acid, ethanol, sulfuric acid, sodium hydroxide, sodium acetate, potassium phosphate, $37 \%$ formaldehyde, biotin, glucosamine and Glucanex were purchased from Sigma-Aldrich (Missouri, USA). Urea was kindly provided by Yara International ASA (Oslo, Norway). Kjeltabs for Kjeldahl analysis were purchased from Thomson and Capper Ltd. (Cheshire, UK). Enzymatic hydrolysates of BALI ${ }^{\mathrm{TM}}$ pretreated spruce were kindly provided by Borregaard AS (Sarpsborg, Norway). The BALI ${ }^{\mathrm{TM}}$ pretreatment [25] involves sulfite pulping of chipped spruce wood (Picea abies), with chip size up to $4.5 \times 4.5 \times 0.8 \mathrm{~cm}$. The carbohydrate composition of the spruce hydrolysate is shown in Supplementary Table S1.

\section{Microorganisms}

Cyberlindnera jadinii LYCC 7549, W. anomalus J121 (CBS 100,487, Swedish University of Agricultural Sciences, Uppsala, Sweden) and B. adeninivorans LS3 (Swedish University of Agricultural Sciences, Uppsala, Sweden) were stored at $-80{ }^{\circ} \mathrm{C}$ in cryovials containing $20 \%(\mathrm{v} / \mathrm{v})$ glycerol and $80 \%(\mathrm{v} / \mathrm{v})$ YPD medium. 


\section{Shake flask experiments and repeated fed-batch fermentations}

\section{Shake flask experiments}

Shake flask batch fermentations were conducted using media composed of spruce sugar hydrolysate (abbreviated as BALI ${ }^{\mathrm{TM}}$, in this study) and different mixtures of poultry hydrolysates and urea. Pre-cultures were prepared by adding $200 \mu \mathrm{L}$ of a thawed seed culture stored at $-80{ }^{\circ} \mathrm{C}$ to $50 \mathrm{~mL}$ of the to-be-tested medium in a $250 \mathrm{~mL}$ baffled shake flask, followed by incubation at $30^{\circ} \mathrm{C}, 220 \mathrm{rpm}$, for $16 \mathrm{~h}$. The initial $\mathrm{pH}$ was adjusted to 5.0 using $5 \mathrm{M} \mathrm{NaOH}$ or $5 \mathrm{M} \mathrm{H}_{2} \mathrm{SO}_{4}$. Shake flasks containing $50 \mathrm{~mL}$ fresh medium were then inoculated with overnight pre-cultures to obtain an initial OD of 0.5 , as measured at $595 \mathrm{~nm}$ with an UV/VIS spectrophotometer (Hitachi U1900, Tokyo, Japan). The shake flasks were incubated at $30{ }^{\circ} \mathrm{C}$ and $220 \mathrm{rpm}$, and samples were taken at $24 \mathrm{~h}$, for the measurement of $\mathrm{pH}$, cell dry weight $(\mathrm{CDW})$, protein content, and soluble sugars. These experiments were performed in duplicates. All media contained $50 \mathrm{~g} / \mathrm{L}$ BALI ${ }^{\mathrm{TM}}$ glucose and $5.86 \mathrm{~g} / \mathrm{L}$ nitrogen. The nitrogen was supplied using six different blends of poultry protein hydrolysates and urea. More specifically, 0, 20, 40, 60, 80 or $100 \%$ of the nitrogen was supplied by urea.

\section{Repeated fed-batch fermentations at $1.5 \mathrm{~L}$ and $25 \mathrm{~L}$ scale}

The bioreactor cultivations were performed in $2.5 \mathrm{~L}$ volume glass fermenters (Minifors, Infors, Bottmingen, Switzerland) with working volumes of $1.5 \mathrm{~L}$, and a $42 \mathrm{~L}$ Techfors S stainless steel bioreactor (Infors, Bottmingen, Switzerland) with $25 \mathrm{~L}$ working volume, both equipped with two six-bladed Rushton impellers. Blends of urea and poultry hydrolysates were autoclaved at $121{ }^{\circ} \mathrm{C}$ for $15 \mathrm{~min}$ in the bioreactors. BALI $^{\text {TM }}$ sugar hydrolysate was autoclaved separately, and aseptically added into the bioreactors.

For repeated fed-batch mode, fresh medium containing poultry hydrolysate and urea was prepared for the $2.5 \mathrm{~L}$ bioreactors sterilizing at $121{ }^{\circ} \mathrm{C}$ for $15 \mathrm{~min}$. For the $42 \mathrm{~L}$ bioreactor, new nitrogen medium was prepared using $80{ }^{\circ} \mathrm{C}$ water in $30 \mathrm{~L}$ Einar hydrolysis reactors (Belach Bioteknik, Skogås, Stockholm, Sweden) and stored at $4{ }^{\circ} \mathrm{C}$ for up to 12-16 h, until use. Also, for the repeated fed-batch experiments, BALI ${ }^{\mathrm{TM}}$ hydrolysate was autoclaved separately.

Overnight pre-cultures were prepared by adding $0.2 \mathrm{~mL}$ or $1.6 \mathrm{~mL}$ of seed culture to $50 \mathrm{~mL}$ or $400 \mathrm{~mL}$ of the selected medium in $250 \mathrm{~mL}$ or $2 \mathrm{~L}$ baffled shake flasks for the $2.5 \mathrm{~L}$ and $42 \mathrm{~L}$ bioreactors, respectively. The pre-cultures were incubated at $30^{\circ} \mathrm{C}, 220 \mathrm{rpm}$ for approx. $16 \mathrm{~h}$, prior to inoculation of the bioreactors, which were inoculated with $3 \%$ (v/v) pre-culture. The temperature for all cultivations was $30{ }^{\circ} \mathrm{C}$. The $\mathrm{pH}$ was monitored with a $\mathrm{pH}$ probe (Mettler
Toledo, Greifensee, Switzerland) and automatically maintained at 5.0 by controlled addition of $5 \mathrm{M} \mathrm{NaOH}$ or $5 \mathrm{M}$ $\mathrm{H}_{2} \mathrm{SO}_{4}$. Dissolved oxygen (DO) was set at $30 \%$ saturation and regulated by automatic adjustment of the stirrer speed (300-1250 rpm). Cultures were aerated through a sparger at an initial rate of $1.5 \mathrm{~L} / \mathrm{min}$ or $25 \mathrm{~L} / \mathrm{min}(1 \mathrm{VVM})$ and a maximum rate of $3 \mathrm{~L} / \mathrm{min}$ or $50 \mathrm{~L} / \mathrm{min}(2 \mathrm{VVM})$, for the $2.5 \mathrm{~L}$ and $42 \mathrm{~L}$ bioreactors, respectively. $\mathrm{CO}_{2}$ and $\mathrm{O}_{2}$ analysis was performed with a FerMac 368 off-gas analyzer (Electrolab Biotech, Tewkesbury, UK) for the $2.5 \mathrm{~L}$ bioreactors and an Infors HT Gas Analyzer (Infors, Bottmingen, Switzerland) for the $42 \mathrm{~L}$ bioreactor. Foam was controlled via a foam sensor with two times diluted Glanapon DB 870 antifoam (Busetti, Vienna, Austria). Fermentation data were recorded using IRIS process control software (Infors). The repeated fed-batch fermentation was carried out using a $V_{\text {out }} / V_{f}$ value of 0.75 (i.e., $75 \%$ of the total volume was harvested and replaced by fresh medium in each cycle). The total cultivation time was kept at $72 \mathrm{~h}$ or $76 \mathrm{~h}$ using cultivation cycles of $8 \mathrm{~h}$ ( 7 cycles) or $12 \mathrm{~h}$ ( 5 cycles), respectively. The first harvest after the initial batch-phase always occurred after $16 \mathrm{~h}$. The cultivation broth was aseptically collected, and a sterilized or pasteurized (the nitrogen medium fraction for the $42 \mathrm{~L}$ bioreactor) fresh medium was added into the fermenters with the use of a peristaltic pump connected to the inoculation port. During the fermentation experiments, samples were taken every $4 \mathrm{~h}$ for analysis of soluble medium components and yeast biomass.

\section{Downstream processing}

Yeast produced during the repeated fed-bath fermentation in the $42 \mathrm{~L}$ bioreactor was collected and kept at $4{ }^{\circ} \mathrm{C}$. The broth, containing the medium and the yeast cells, was centrifuged using a GEA Westfalia Separator Easyscale 10.S (GEA, Bönen, Germany) with a flowrate of $70 \mathrm{~L} / \mathrm{h}$ and discharge every $120 \mathrm{~s}$. The phase containing the yeast was resuspended in water $(1: 1, \mathrm{v} / \mathrm{v})$ and washed one time with tap water using a flowrate of $50 \mathrm{~L} / \mathrm{h}$ and $90 \mathrm{~s}$ discharge time. Different aliquots were stored as a yeast paste (i.e., a dry matter content of approximately $15 \%$ ) at $-20{ }^{\circ} \mathrm{C}$ until further use.

For disruption experiments, $25 \mathrm{~mL}$ thawed cell paste was transferred to a $50 \mathrm{~mL}$ falcon tube and water was added up to $50 \mathrm{~mL}$ to wash the cells. After collecting the cells using a centrifuge at $4{ }^{\circ} \mathrm{C}$ and $4700 \mathrm{~g}$ for $5 \mathrm{~min}$, the washing step was repeated once. An autolysis treatment was carried out by incubating washed yeast cells in water $(7.5 \% \mathrm{DM})$ at $55^{\circ} \mathrm{C}$ for $20 \mathrm{~h}$ at $220 \mathrm{rpm}$ without $\mathrm{pH}$ adjustment. A hydrolytic treatment with Glucanex was done using an identical cell suspension, which was supplemented with 1:200 (w/w) Glucanex with $200 \mathrm{mM} \mathrm{NaOAc} \mathrm{pH} 6$ (hydrolytic treatment with Glucanex), followed by incubation at $37{ }^{\circ} \mathrm{C}$ for 
$24 \mathrm{~h}$ at $220 \mathrm{rpm}$. Identical 7.5\% DM cell suspensions were also subjected to a mechanical treatment (cell disruption by high-pressure homogenization) using a microfluidizer (Microfluidizer ${ }^{\mathrm{TM}}$ SIMATIC HMI LM20) at 30.000 psi, for three consecutive cycles. The cell suspensions subjected to autolysis, hydrolytic treatment with Glucanex, homogenization with a microfluidizer and to no treatment were frozen at $-80{ }^{\circ} \mathrm{C}$, and then freeze dried using an Alpha 2-4 LD plus freeze drier (Martin Christ, Osterode am Harz. Germany) set at $-60{ }^{\circ} \mathrm{C}$ and $0.01 \mathrm{mbar}$ for a minimum of $24 \mathrm{~h}$ until the samples were dry. All these experiments were performed in triplicates. The whole process flow of this study is shown in Supplementary Figure S1.

\section{Analytical methods}

\section{Cell dry weight (CDW)}

Fermentation broth samples $(50 \mathrm{~mL}$ for shake flasks, $25 \mathrm{~mL}$ for bioreactors) were centrifuged at $4700 \mathrm{~g}$ for $5 \mathrm{~min}$ at $4{ }^{\circ} \mathrm{C}$ and the supernatant was collected for further analyses (sugars, organic acids, ethanol, protein). Then, the yeast biomass was washed twice with cold distilled water, frozen at $-80{ }^{\circ} \mathrm{C}$ and then freeze dried using an Alpha 2-4 LDplus freeze drier (Martin Christ, Osterode am Harz, Germany) at $-60{ }^{\circ} \mathrm{C}$ and 0.01 mbar vacuum for a minimum of $24 \mathrm{~h}$ until samples were dry. The dried cells were weighed to determine $\mathrm{CDW}$, and were also used for analysis of protein content and amino acids.

\section{Monosaccharides, organic acids and ethanol}

Monosaccharides (D-glucose, D-xylose), organic acids (lactic acid, acetic acid) and ethanol present in the fermentation broth were analyzed by high-performance liquid chromatography (HPLC) with refractive index detection. The samples were diluted ten times with distilled water and $200 \mu \mathrm{L}$ of the diluted sample was vacuum filtered using 96-well filter plates $(0.45 \mu \mathrm{m})$. Samples were separated on a Rezex ROAorganic acid $\mathrm{H}+, 300 \times 7.8 \mathrm{~mm}$ (Phenomenex, Torrance, CA, USA) analytical column fitted with a cation-H cartridge guard column, using a column temperature of $65^{\circ} \mathrm{C}, 5 \mathrm{mM}$ $\mathrm{H}_{2} \mathrm{SO}_{4}$ as eluent and a flow rate of $0.6 \mathrm{~mL} / \mathrm{min}$.

\section{Protein content}

The total nitrogen content of the poultry hydrolysates and the freeze-dried yeast biomass was measured according to the Kjeldahl method (European Commission [EC] regulation No: 152/2009, pp 15-19) using a Kjeltec TM 8400 (FOSS, Tecator, Hoganas, Sweden) after acid digestion in an autodigestor (FOSS, Tecator, Hoganas, Sweden). The protein content of samples was estimated by multiplying total nitrogen by a factor of 6.25 .

\section{Amino acids}

Analysis of the content of amino acids (except tryptophan) in freeze-dried yeast was performed according to EC regulation No: 152/2009 (pp. 23-32) using a Biochrom 30 amino acid analyzer (Biochrom Ltd., Cambridge, UK). Tryptophan was analyzed according to EC regulation No: 152/2009 (pp. 32-37) using a Dionex Ultimate 3000 HPLC system (Dionex Softron GmbH, Germering, Germany) connected to a RF-535 fluorescence detector (Shimadzu., Kyoto, Japan). All amino acids were quantified using external standards (Dionex Ltd., Surrey, UK).

\section{Scanning electron microscope (SEM)}

For SEM images, the yeast cell suspensions were mixed with $37 \%(\mathrm{v} / \mathrm{v})$ formaldehyde reaching a final concentration of $3.7 \%$, and incubated at room temperature for $20 \mathrm{~min}$. The yeast suspensions were then centrifuged for $5 \mathrm{~min}$ at $8000 \mathrm{~g}$, resuspended in $0.1 \mathrm{M}$ potassium phosphate and kept at $4{ }^{\circ} \mathrm{C}$ until imaging. Prior to scanning electron microscopy, the cells were washed several times in $0.05 \mathrm{M}$ Pipes buffer, $\mathrm{pH}$ 7.0 , and dehydrated with 10 min stages in ascending ethanol series (30-100\%). The samples were processed in a BALTEC Critical Point Dryer (CPD 030, Witten, Germany) and a thin conductive coating of gold/palladium was applied to the samples using a Polaron Sputter Coater (SC 7640, Kent, UK). The coated samples were mounted on brass stubs and examined and photographed with a Zeiss EVO-50-EP scanning electron microscope at an accelerating voltage of $15 \mathrm{kV}$ in the secondary emission mode.

\section{Statistical analysis}

Data handling and statistics were performed using the Excel software package (Microsoft Excel 2013, Microsoft Corp., Redmond, WA).

\section{Results and discussion}

\section{Characterization of $\mathrm{BALI}^{\mathrm{Tm}}$ and poultry hydrolysates}

Supplementary Table S1 shows that glucose is the main carbon source in the spruce BALI ${ }^{\mathrm{TM}}$ hydrolysates constituting $76 \%$ of the total sugar. The protein content of the protein-rich hydrolysates (named poultry hydrolysates in this study), based on the Kjeldahl method, was $444 \pm 1 \mathrm{~g} / \mathrm{L}$. In the growth experiments described below, carbohydrates 
were dosed based on glucose, whereas the nitrogen source was dosed based on nitrogen.

\section{Preliminary $1.5 \mathrm{~L}$ batch fermentations using poultry hydrolysates}

Initially, several batch fermentations were carried out at $1.5 \mathrm{~L}$ scale in bioreactors to compare the growth performance of the three yeast strains growing on a blend of BALI $^{\mathrm{TM}}$ sugars and poultry protein hydrolysate. Supplementary Table $\mathrm{S} 2$ shows the CDW (g/L) and protein content (\%) after $12 \mathrm{~h}$ and $24 \mathrm{~h}$. In general, all the yeast strains had a protein content in the range $47-51 \%$ after $12 \mathrm{~h}$ of fermentation, but prolonged incubation somewhat reduced this. $C$. jadinii showed both the slowest growth rate and the lowest final production of microbial biomass. Both $W$. anomalus and $B$. adeninivorans grew faster and achieved a much higher biomass concentration after $24 \mathrm{~h}$, in particular $B$. adeninivorans which reached a CDW of $44.0 \mathrm{~g} / \mathrm{L}$ (as compared to $29.7 \mathrm{~g} / \mathrm{L}$ and $18.0 \mathrm{~g} / \mathrm{L}$ for $W$. anomalus and C. jadinii, respectively). This is in the same range as fed-batch cultures of $C$. intermedia growing on corncob hydrolysates which reached a $\mathrm{CDW}$ of $34.6 \mathrm{~g} / \mathrm{L}$ after $40 \mathrm{~h}$ of incubation [26]. In another study, $C$. jadinii grown on rice polishing in batch reached a CDW of $50 \mathrm{~g} / \mathrm{L}$ after $65 \mathrm{~h}$ [27]. A similar trend has been observed previously for these three yeast strains when grown on a medium composed of BALI ${ }^{\mathrm{TM}}$ sugars and an in-house prepared chicken hydrolysate (results not shown). Thus, in these batch fermentations, $B$. adeninivorans showed superior growth performance, probably due the good ability of this yeast to utilize peptides as a carbon source [28]. Of note, however, $B$. adeninivorans showed the lowest protein content after $24 \mathrm{~h}(41.9 \%)$.

\section{Assessing the ratio of organic and inorganic nitrogen}

To test the importance of the protein hydrolysate for growth, a screening of growth was performed where different amounts of protein hydrolysate were substituted with inorganic nitrogen (urea). The experiments were conducted in shake flasks and the results in terms of CDW $(\mathrm{g} / \mathrm{L})$ and protein content (\%) are shown in Figs. 1 and 2, respectively. After $24 \mathrm{~h}$, the growth based on cell dry weight was between 9.8 and $13.2 \mathrm{~g} / \mathrm{L}$ for all the yeasts and all fermentations containing poultry hydrolysates (100-20\%). When only urea was used as a nitrogen source (condition 6), there was hardly any growth (note that the protein content for

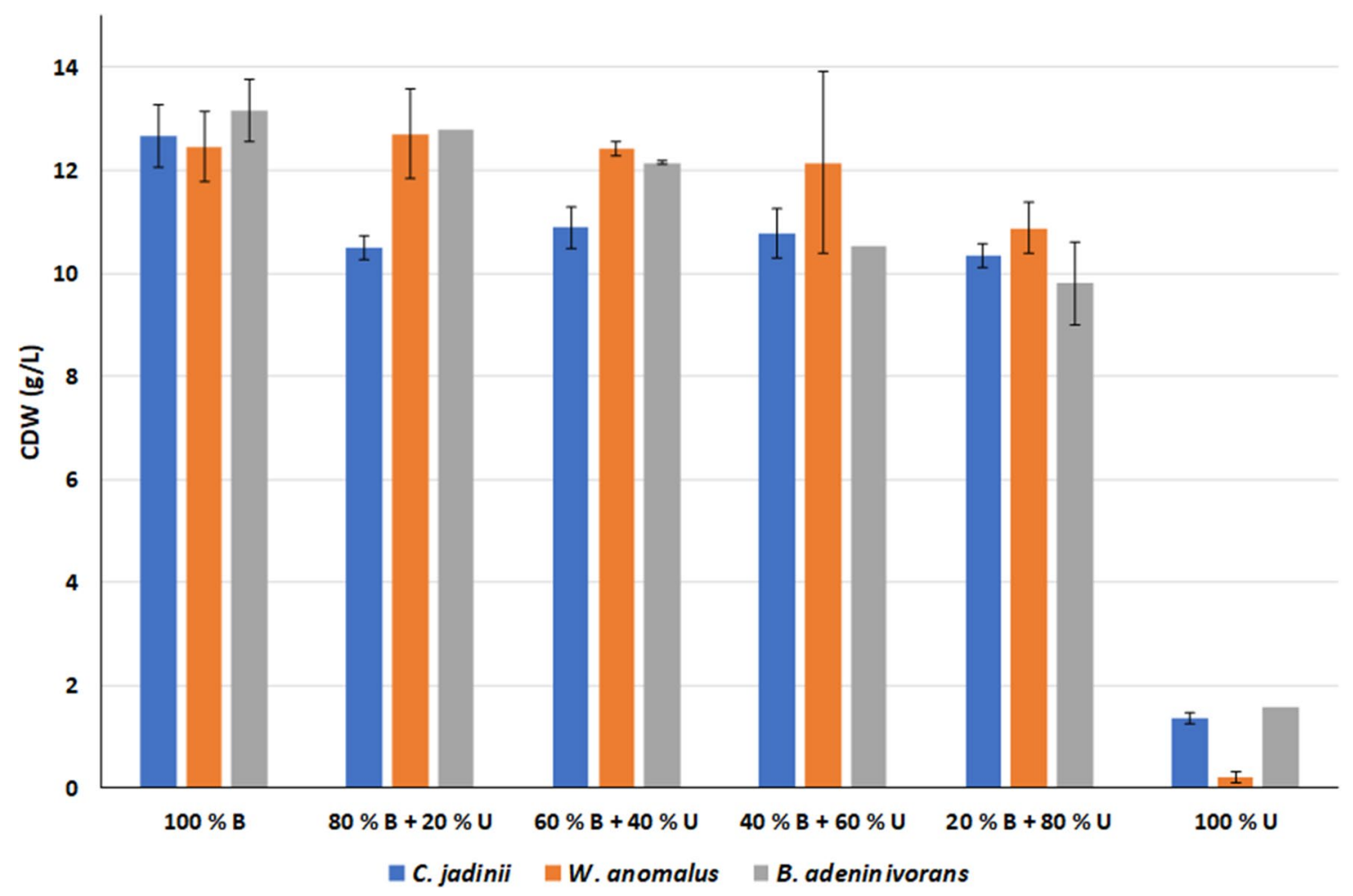

Fig. 1 Growth of three yeast strains in shake flasks using six different media using different combinations of poultry hydrolysates and urea. The graph shows $\mathrm{CDW}(\mathrm{g} / \mathrm{L})$ after $24 \mathrm{~h}$ cultivation (values are mean $\pm \mathrm{SD} ; n=2) . B$ BIOCO poultry hydrolysates, $U$ Urea. Condi- tions: Glucose, $50 \mathrm{~g} / \mathrm{L}$; Kjeldahl nitrogen, $5.86 \mathrm{~g} / \mathrm{L} ; \mathrm{OD}_{\text {initial }}=0.5$; volume: $50 \mathrm{~mL} ; \mathrm{pH}_{\text {initial }}=5.0$; incubation at $30{ }^{\circ} \mathrm{C}$ with $220 \mathrm{rpm}$ shaking. The $\mathrm{pH}$ and $\mathrm{pO}_{2}$ were not controlled 


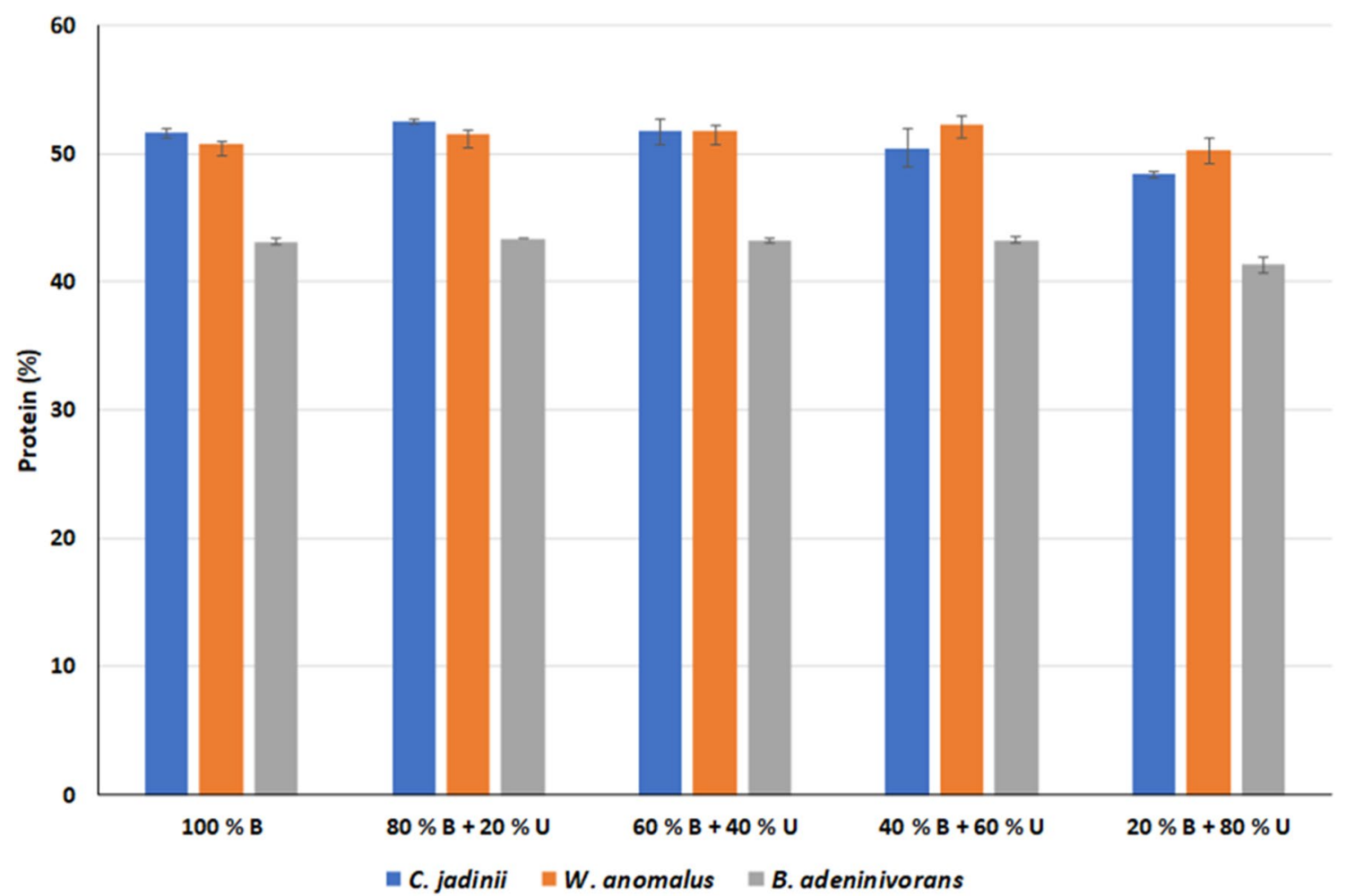

Fig. 2 Protein content of three yeast strains grown in shake flasks using five different media using different combinations of poultry hydrolysates and urea. The graph shows protein content (\%) after $24 \mathrm{~h}$ cultivation (values are mean $\pm \mathrm{SD} ; n=2$ ). $B$ BIOCO poultry hydrolysates, $U$ Urea. Conditions: Glucose, $50 \mathrm{~g} / \mathrm{L}$; Kjeldahl nitrogen,

condition 6 could not be determined due to the lack of sufficient amounts of microbial biomass for the analysis). The observed growth yields were much lower than $50 \%$ (in this case, $25 \mathrm{~g} / \mathrm{L}$ ) which is typically achieved for yeast under aerobic conditions [29]. Analysis of the supernatants after 24 h showed that glucose was completely consumed for $C$. jadinii and $W$. anomalus, while B. adeninivorans did not consume all glucose (data not shown). Without protein hydrolysate in the medium, less than $20 \%$ of the glucose was consumed for any yeast. Ethanol concentrations between 17.0 and $24.7 \mathrm{~g} / \mathrm{L}$ were observed for all the $C$. jadinii and $W$. anomalus cultivations containing poultry hydrolysates. For $B$. adeninivorans, ethanol concentrations were in the range of $4.8-11.7 \mathrm{~g} / \mathrm{L}$ (data not shown). The $\mathrm{pH}$ was measured after $24 \mathrm{~h}$ (data not shown), and it was observed that the buffer capacity decreased when less poultry hydrolysate was included in the medium, with $\mathrm{pH}$ values after $24 \mathrm{~h}$ being $4.77,4.36$ and 4.50 in the cultures with $80 \%$ poultry hydrolysate and 20\% urea, and 4.30, 3.89 and 3.32 in the cultures with $20 \%$ poultry hydrolysate and $80 \%$ urea, for $C$. jadinii, $W$. anomalus, and B. adeninivorans, respectively. In the cultures with only urea, the final $\mathrm{pH}$ values varied between 5.53 and 5.81. Acetic acid was also measured and concentrations
$5.86 \mathrm{~g} / \mathrm{L} ; \mathrm{OD}_{\text {initial }}=0.5$; volume: $50 \mathrm{~mL} ; \mathrm{pH}_{\text {initial }}=5.0$; incubation at $30{ }^{\circ} \mathrm{C}$ with $220 \mathrm{rpm}$ shaking. The $\mathrm{pH}$ and $\mathrm{pO}_{2}$ were not controlled. The protein content in cells grown on urea only (see Fig. 1) was not determined

ranged between 0 and $3 \mathrm{~g} / \mathrm{L}$ (data not shown). All in all, these results show that the shake flask cultures were clearly limited regarding oxygen supply, causing high ethanol concentrations, and by medium acidification.

The general trends visible in Figs. 1 and 2 are that biomass production went down as the amount of poultry hydrolysates was reduced, whereas the protein content of the cells, around $50 \%$ for $C$. jadinii and $W$. anomalus and $43 \%$ for $B$. adeninivorans, was hardly affected. Although the differences in growth are likely primarily due to $\mathrm{pH}$ effects, the data in Figs. 1 and 2 do make clear that the cells can not simply convert urea to protein, but also that they need some of the components provided by the poultry hydrolysate (since on urea only growth was strongly restricted). It is well known that inorganic nitrogen can provide a considerable amount of nitrogen when combined with an organic nitrogen source that supplies additional benefits such as various trace elements $[29,30]$.

\subsection{Bioreactor runs}

Shake flask experiments suffer from a lack of $\mathrm{pH}$ control, as well as sub-optimal aeration $\left(\mathrm{pO}_{2}\right)$ and stirring. Therefore, 
C. jadinii, W. anomalus and B. adeninivorans were cultivated in $2.5 \mathrm{~L}$ fermenters in repeated fed-batch mode. The main objectives were to identify the best medium ratios of poultry hydrolysate and urea to support high productivity $\left(Q_{x}\right)$, while producing yeast biomass containing around $50 \%$ protein $[6,18]$.

\section{Using $100 \%$ poultry hydrolysates}

We then carried out repeated fed-batch fermentations in 1.5 L fermenters with all three yeast, using $100 \%$ poultry hydrolysate as nitrogen source. Raw data from these fermentations are provided in Supplementary Figure S2, while Table 1 summarizes the key features. This procedure worked very well for $C$. jadinii and $W$. anomalus but not for $B$. adeninivorans, which left much of the glucose unused and, thus, showed low productivity. $C$. jadinii and $W$. anomalus used most of the glucose, showed good biomass productivity, amounting to 2.51 and $2.61 \mathrm{~g} / \mathrm{L} / \mathrm{h}$, respectively. This is clearly higher than productivities of 1.15 and $0.86 \mathrm{~g} / \mathrm{L} / \mathrm{h}$ achieved for other candida strains produced on

Table 1 Growth characteristics for $1.5 \mathrm{~L}$ repeated fed-batch fermentations of C. jadinii, W. anomalus and B. adeninivorans grown on $100 \%$ poultry hydrolysates and BALI ${ }^{\mathrm{TM}}$ hydrolysates

\begin{tabular}{llll}
\hline & $C$. jadinii & W. anomalus & B. adeninivorans \\
\hline $\begin{array}{l}\text { Increase in CDW } \\
\quad(\mathrm{g} / \mathrm{L})^{\mathrm{a}}\end{array}$ & $20.05 \pm 2.01$ & $20.87 \pm 2.44$ & $14.69 \pm 8.62$ \\
$\begin{array}{l}\text { Protein }(\%) \\
\text { Increase in protein }\end{array}$ & $40.89 \pm 1.54$ & $48.38 \pm 0.91$ & $47.44 \pm 2.77$ \\
$\quad(\mathrm{~g} / \mathrm{L})^{\mathrm{a}}$ & & & \\
Unconsumed glucose & $2.90 \pm 1.55$ & $0.99 \pm 0.77$ & $25.06 \pm 8.72$ \\
$\quad(\mathrm{~g} / \mathrm{L})$ & & & \\
$Y_{X / \text { glucose }}^{\mathrm{b}}$ & 0.48 & 0.54 & 0.50 \\
$Y_{\mathrm{X} / \text { sugars }}^{\mathrm{c}}$ & 0.37 & 0.41 & 0.38 \\
$Y_{\mathrm{p} / \mathrm{glucose}}^{\mathrm{b}}$ & 0.20 & 0.26 & 0.24 \\
$Y_{\mathrm{p} / \mathrm{sugars}}^{\mathrm{c}}$ & 0.15 & 0.20 & 0.18 \\
$Q_{x}^{\mathrm{d}}$ & 2.51 & 2.61 & 1.51 \\
$Q_{p}^{\mathrm{e}}$ & 1.02 & 1.26 & 0.71 \\
\hline
\end{tabular}

The $V_{\text {out }} / V_{f}$ was 0.75 , every $8 \mathrm{~h}$, and starting at $16 \mathrm{~h}$. The data shown are average values for the samples taken at $24 \mathrm{~h}$ and at the end of the subsequent six repeated batches (32-72 h). The nitrogen concentration in the medium was $5.86 \mathrm{~g} / \mathrm{L}$, whereas the glucose concentration was approximately $50 \mathrm{~g} / \mathrm{L}$ (the actual glucose concentrations were measured by HPLC at each sampling point and right after each harvest/refill procedure, and these measurements were used for the calculations). Supplementary Figure S2 provides the actual values of the parameters during the course of the fermentation

${ }^{\mathrm{a}}$ Increase over the $8 \mathrm{~h}$ growth period following each harvest/refill procedure

${ }^{\mathrm{b}}$ Yield of cell biomass $(\mathrm{X})$ or protein $(\mathrm{P})$ per consumed glucose

${ }^{\mathrm{c}}$ Yield of cell biomass $(\mathrm{X})$ or protein $(\mathrm{P})$ per total added sugar

${ }^{\mathrm{d}}$ Cell biomass productivity in $\mathrm{g} / \mathrm{L} / \mathrm{h}$

${ }^{\mathrm{e}}$ Protein productivity in $\mathrm{g} / \mathrm{L} / \mathrm{h}$ rice polishing [27] and corncob hydrolysates [26], respectively. For continuous cultures of $C$. jadinii using molasses as carbon source, a maximum productivity of $2.15 \mathrm{~g} / \mathrm{L} / \mathrm{h}$ has been reported [31]. The protein content of the cells produced in our study was $40.9 \%$ and $48.4 \%$ for C. jadinii and $W$. anomalus, respectively. While $C$. jadinii reached high cell densities, this came at the cost of lower protein content. A similar trade-off between cell mass and protein content was observed by Sharma et al. [32]. Overall, W. anomalus was clearly the best protein producer when grown in medium containing the poultry hydrolysate as the only nitrogen source.

\section{Using $40 \%$ poultry hydrolysate and $60 \%$ urea}

Inorganic nitrogen is cheaper than protein hydrolysates and may be easier to take up and metabolize. Thus, substituting part of the protein hydrolysate with inorganic nitrogen may be beneficial. The same set of fermentation experiments were repeated, but this time, $60 \%$ of the nitrogen in the protein hydrolysate was substituted with urea nitrogen. Compared to the fermentations using $100 \%$ poultry hydrolysates as $\mathrm{N}$ source, the cell biomass production substantially changed for W.anomalus (increased from 20.9 to $28.9 \mathrm{~g} / \mathrm{L}$ ) but the protein content decreased to $37.7 \%$ (Table 2; raw data in Supplementary Figure S3). For $C$. jadinii, the protein content increased to $44.9 \%$, while biomass production was similar to the fermentation with $100 \%$ poultry. The $B$. adeninivorans fermentations showed better performance than in the fermentations with $100 \%$ poultry hydrolysate, but did still not consume glucose very well, indicating that the fermentation strategy still was not optimal for this yeast. In accordance with previous observations, $B$. adeninivorans performed better than expected on the basis of the low glucose consumption, which is likely due to the ability of this yeast to effectively use peptides in the poultry hydrolysate as carbon source [28].

All in all, comparing the results of Table 1 (100\% poultry hydrolysate) and Table 2 (40\% poultry hydrolysate) does not provide immediate clues for further optimization of the process. However, this comparison clearly shows that varying the ratio of the organic and the inorganic nitrogen source has considerable effects.

\section{Using $60 \%$ poultry hydrolysates with $40 \%$ urea}

The experiments described above showed that W. anomalus had the highest productivity regarding both biomass ( $Q_{x}$ in the range 2.61-3.61) and protein $\left(Q_{P}\right.$ in the range 1.26-1.36) production, although it must be noted that the higher productivities depicted in Table 2 come at the cost of a low protein content of the cells. We have previously seen that $B$. adeninivorans outperformed $C$. jadinii and $W$. 
Table 2 Growth characteristics for $1.5 \mathrm{~L}$ repeated fed-batch fermentations of $C$. jadinii, $W$. anomalus and $B$. adeninivorans grown on

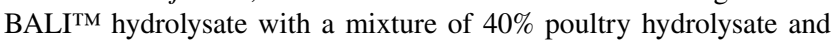
$60 \%$ urea as nitrogen source

\begin{tabular}{llll}
\hline & $C$. jadinii & W. anomalus & B. adeninivorans \\
\hline $\begin{array}{l}\text { Increase in CDW } \\
\quad(\mathrm{g} / \mathrm{L})^{\mathrm{a}}\end{array}$ & $21.08 \pm 1.45$ & $28.88 \pm 1.11$ & $18.51 \pm 3.18$ \\
Protein (\%) & $44.87 \pm 4.03$ & $37.66 \pm 2.19$ & $44.45 \pm 3.16$ \\
$\begin{array}{l}\text { Increase in protein } \\
\quad(\mathrm{g} / \mathrm{L})^{\mathrm{a}}\end{array}$ & $9.43 \pm 1.69$ & $10.88 \pm 0.89$ & $8.19 \pm 1.31$ \\
$\quad$ Unconsumed glucose & $3.48 \pm 2.50$ & $0.55 \pm 0.13$ & $25.53 \pm 6.83$ \\
$\quad(\mathrm{~g} / \mathrm{L})$ & & & \\
$Y_{\mathrm{X} / \mathrm{glucose}}^{\mathrm{b}}$ & 0.55 & 0.69 & 0.89 \\
$Y_{\mathrm{X} / \text { sugars }}^{\mathrm{c}}$ & 0.41 & 0.53 & 0.68 \\
$Y_{\mathrm{p} / \mathrm{glucose}}^{\mathrm{c}}$ & 0.24 & 0.26 & 0.39 \\
$Y_{\mathrm{p} / \text { sugars }}^{\mathrm{d}}$ & 0.19 & 0.20 & 0.30 \\
$Q_{x}^{\mathrm{d}}$ & 2.63 & 3.61 & 2.31 \\
$Q_{p}^{\mathrm{e}}$ & 1.18 & 1.36 & 1.02 \\
\hline
\end{tabular}

The $V_{\text {out }} / V_{f}$ was 0.75 , every $8 \mathrm{~h}$, and starting at $16 \mathrm{~h}$. The data shown are average values for the samples taken at $24 \mathrm{~h}$ and at the end of the subsequent six repeated batches (32-72 h). The nitrogen concentration in the medium was $5.86 \mathrm{~g} / \mathrm{L}$, whereas the glucose concentration was approximately $50 \mathrm{~g} / \mathrm{L}$ (the actual glucose concentrations were measured by HPLC at each sampling point and right after each harvest/refill procedure, and these measurements were used for the calculations). Supplementary Figure S3 provides the actual values of the parameters during the course of the fermentation

${ }^{a}$ Increase over the $8 \mathrm{~h}$ growth period following each harvest/refill procedure

${ }^{b}$ Yield of cell biomass $(\mathrm{X})$ or protein $(\mathrm{P})$ per consumed glucose

${ }^{c}$ Yield of cell biomass $(\mathrm{X})$ or protein $(\mathrm{P})$ per total added sugar

${ }^{\mathrm{d}}$ Cell biomass productivity in $\mathrm{g} / \mathrm{L} / \mathrm{h}$

${ }^{e}$ Protein productivity in $\mathrm{g} / \mathrm{L} / \mathrm{h}$

anomalus during batch fermentations using BALI ${ }^{\mathrm{TM}}$ hydrolysates and in-house generated chicken hydrolysates, due to its ability to not only grow on sugars but also on different nitrogen sources [28, 33]. In the repeated fed-batch setup used in this study, B. adeninivorans had not been able to consume the glucose during the $8 \mathrm{~h}$ cycles. Thus, in a next series of experiments, this time using $60 \%$ poultry and $40 \%$ urea as nitrogen source, the cycle time for $B$. adeninivorans was increased to $12 \mathrm{~h}$ in an attempt to obtain better glucose utilization. The results, summarized in Table 3 (raw data in Supplementary Figure S4), show that the longer cycle time indeed resulted in increased consumption of glucose and that glucose consumption was more stable. However, sugar consumption was still not complete and, moreover, performance wise (yields, productivities, protein content; see Table 3), the longer cycle time did not improve the overall process. For $W$ anomalus, the change from 40 to $60 \%$ poultry hydrolysate resulted in improved performance such as a higher protein content (41.2\% versus $37.7 \%$ ) and higher
Table 3 Growth characteristics for $1.5 \mathrm{~L}$ repeated fed-batch fermentations of $W$. anomalus and B. adeninivorans grown on BALI ${ }^{\mathrm{TM}}$ hydrolysate with a mixture of $60 \%$ poultry hydrolysate and $40 \%$ urea as nitrogen source

\begin{tabular}{lll}
\hline & W. anomalus & B. adeninivorans \\
\hline Increase in CDW $(\mathrm{g} / \mathrm{L})^{\mathrm{a}}$ & $29.78 \pm 3.51$ & $27.62 \pm 1.30$ \\
Protein $(\%)$ & $41.22 \pm 1.19$ & $42.45 \pm 1.12$ \\
${\text { Increase in protein }(\mathrm{g} / \mathrm{L})^{\mathrm{a}}}$ & $12.24 \pm 1.14$ & $11.73 \pm 0.67$ \\
Unconsumed glucose $(\mathrm{g} / \mathrm{L})$ & $0.15 \pm 0.03$ & $11.37 \pm 2.83$ \\
$Y_{\mathrm{X} / \text { glucose }}^{\mathrm{b}}$ & 0.71 & 0.81 \\
$Y_{\mathrm{X} / \text { sugars }}^{\mathrm{c}}$ & 0.54 & 0.61 \\
$Y_{\mathrm{p} / \text { glucose }}^{\mathrm{b}}$ & 0.29 & 0.34 \\
$Y_{\mathrm{p} / \text { sugars }}^{\mathrm{d}}$ & 0.22 & 0.26 \\
$Q_{x}^{\mathrm{d}}$ & 3.72 & 2.30 \\
$Q_{p}^{\mathrm{e}}$ & 1.53 & 0.98 \\
\hline
\end{tabular}

The $V_{\text {out }} / V_{f}$ was 0.75 , every $8 \mathrm{~h}$ (W. anomalus) or every $12 \mathrm{~h}$ (B. adeninivorans), and starting at $16 \mathrm{~h}$. The data shown are average values for the samples taken at $24 \mathrm{~h}$ and $28 \mathrm{~h}$, respectively, and at the end of the subsequent six (W. anomalus) or four (B. adeninivorans) repeated batches. The nitrogen concentration in the medium was $5.86 \mathrm{~g} / \mathrm{L}$, whereas the glucose concentration was approximately $50 \mathrm{~g} / \mathrm{L}$ (the actual glucose concentrations were measured by HPLC at each sampling point and right after each harvest/refill procedure, and these measurements were used for the calculations). Supplementary Figure $\mathrm{S} 4$ provides the actual values of the parameters during the course of the fermentation

${ }^{\text {a } I n c r e a s e}$ over the $8 \mathrm{~h}$ growth period following each harvest/refill procedure

${ }^{\mathrm{b}}$ Yield of cell biomass $(\mathrm{X})$ or protein $(\mathrm{P})$ per consumed glucose

${ }^{\mathrm{c}}$ Yield of cell biomass $(\mathrm{X})$ or protein $(\mathrm{P})$ per total added sugar

${ }^{\mathrm{d}}$ Cell biomass productivity in $\mathrm{g} / \mathrm{L} / \mathrm{h}$

${ }^{\text {e}}$ Protein productivity in $\mathrm{g} / \mathrm{L} / \mathrm{h}$

productivity of both cell biomass ( 3.72 versus $3.61 \mathrm{~g} / \mathrm{L} / \mathrm{h}$ ) and protein (1.53 versus $1.36 \mathrm{~g} / \mathrm{L} / \mathrm{h})$.

\section{Using $60 \%$ poultry hydrolysate and $40 \%$ urea with biotin, and $80 \%$ poultry hydrolysate with $20 \%$ urea}

In the experiments described above, W. anomalus was superior in terms of productivity, but in several of the fermentations, the protein content of the cells was rather low. In particular, while $W$. anomalus grew well on urea, replacement of poultry hydrolysate with urea led to lowered protein contents (e.g. $48.4 \%$ with $100 \%$ poultry hydrolysate, versus $37.7 \%$ with $40 \%$ poultry hydrolysate and $60 \%$ urea). Yeasts can assimilate urea in two different ways, either via the action of an extracellular urease leading to ammonia production or via import of urea and subsequent assimilation through the urea and amydolyase pathway [34]. In this latter case, addition of biotin is necessary since it works as a cofactor of the urea amidolyase [34]. Therefore, we carried out an additional experiment with the medium composed of $60 \%$ poultry hydrolysate and $40 \%$ urea and added $0.4 \mathrm{mg}$ of 
biotin per gram of urea. Additionally, a repeated fed-batch fermentation was run using a medium composed of $80 \%$ poultry hydrolysate and $20 \%$ urea, without addition of biotin . Supplementary Figure S5 and Table 4 show that the addition of biotin had no significant effect on the production of cell biomass and the protein content, which were $30.00 \mathrm{~g} / \mathrm{L}$ and $40.6 \%$, respectively, compared to $29.8 \mathrm{~g} / \mathrm{L}$ and $41.2 \%$ for the similar experiment without added biotin (Table 3 ).

Supplementary Figure S5 and Table 4 also show that the protein content increased to $45.0 \%$ after increasing the amount of poultry hydrolysates from 60 to $80 \%$, while the production of cell biomass stayed at as high $27.0 \mathrm{~g} / \mathrm{L}$. The latter value is slightly lower than the value obtained with $60 \%$ poultry, but still much higher than the value of $20.9 \mathrm{~g} / \mathrm{L}$ obtained with $100 \%$ poultry. Apparently, having some urea in the medium is highly favorable for cell biomass

Table 4 Growth characteristics for $1.5 \mathrm{~L}$ repeated fed-batch fermentations of $W$. anomalus grown on BALI ${ }^{\mathrm{TM}}$ hydrolysate with two different mixtures of poultry hydrolysate and urea as nitrogen source (60-40, with added biotin or 80-20)

\begin{tabular}{lll}
\hline & W. anomalus & \\
\cline { 2 - 3 } & $\begin{array}{l}\text { Poultry hydro- } \\
\text { lysate 60\%+UREA } \\
40 \%+\text { Biotin }\end{array}$ & $\begin{array}{l}\text { Poultry hydrolysate } \\
80 \%+\text { UREA 20\% }\end{array}$ \\
\hline $\begin{array}{ll}\text { Increase in CDW } \\
(\mathrm{g} / \mathrm{L})^{\mathrm{a}}\end{array}$ & $30.00 \pm 2.07$ & $27.04 \pm 1.55$ \\
Protein $(\%)$ & $40.61 \pm 0.48$ & $45.03 \pm 0.81$ \\
Increase in protein & $12.18 \pm 0.75$ & $12.17 \pm 0.53$ \\
$\quad(\mathrm{~g} / \mathrm{L})^{\mathrm{a}}$ & & \\
Unconsumed glucose & $0.19 \pm 0.01$ & $0.19 \pm 0.03$ \\
$\quad(\mathrm{~g} / \mathrm{L})$ & & 0.62 \\
$Y_{\mathrm{X} / \text { glucose }}^{\mathrm{b}}$ & 0.65 & 0.47 \\
$Y_{\mathrm{X} / \text { sugars }}^{\mathrm{c}}$ & 0.49 & 0.28 \\
$Y_{\mathrm{p} / \mathrm{glucose}}^{\mathrm{b}}$ & 0.26 & 0.21 \\
$Y_{\mathrm{p} / \text { sugars }}^{\mathrm{c}}$ & 0.20 & 3.38 \\
$Q_{x}^{\mathrm{d}}$ & 3.75 & 1.52 \\
$Q_{p}^{\mathrm{e}}$ & 1.52 &
\end{tabular}

The $V_{\text {out }} / V_{f}$ was 0.75 , every $8 \mathrm{~h}$, starting at $16 \mathrm{~h}$. The data shown are average values for the samples taken at $24 \mathrm{~h}$ and at the end of the subsequent six repeated batches (32-72 h). The nitrogen concentration in the medium was $5.86 \mathrm{~g} / \mathrm{L}$, whereas the glucose concentration was approximately $50 \mathrm{~g} / \mathrm{L}$ (the actual glucose concentrations were measured by HPLC at each sampling point and right after each harvest/refill procedure, and these measurements were used for the calculations). Supplementary Figure S5 provides the actual values of the parameters during the course of the fermentation

${ }^{\mathrm{a}}$ Increase over the $8 \mathrm{~h}$ growth period following each harvest/refill procedure

${ }^{\mathrm{b}}$ Yield of cell biomass $(\mathrm{X})$ or protein $(\mathrm{P})$ per consumed glucose

${ }^{\mathrm{c}}$ Yield of cell biomass $(\mathrm{X})$ or protein $(\mathrm{P})$ per total added sugar

${ }^{\mathrm{d}}$ Cell biomass productivity in $\mathrm{g} / \mathrm{L} / \mathrm{h}$

${ }^{\mathrm{e}}$ Protein productivity in $\mathrm{g} / \mathrm{L} / \mathrm{h}$ production. All in all, the run with $80 \%$ poultry hydrolysate seemed close to optimal, yielding productivity values of 3.38 and $1.52 \mathrm{~g} / \mathrm{L} / \mathrm{h}$ for cell biomass and protein, respectively.

\section{L Bioreactor run}

Based on the observations and considerations described above, the combination of $80 \%$ poultry hydrolysate with $20 \%$ urea was selected as medium for upscaling the repeated fed-batch fermentation with $W$. anomalus from 1.5 to $25 \mathrm{~L}$. Figure 3 shows that the 1.5 and $25 \mathrm{~L}$ fermentations behaved rather similar, but with somewhat higher $Q_{x}(3.92 \mathrm{~g} / \mathrm{L} / \mathrm{h})$ and $Q_{P}(1.87 \mathrm{~g} / \mathrm{L} / \mathrm{h})$, as well as a higher protein content $(47.8 \%)$ in the large-scale fermentation (see Tables 4,5 ). The biomass yield was $0.66 \mathrm{~g}$ biomass per $\mathrm{g}$ of glucose, which is in the higher range of yields report for aerobic growth of yeast, typically ranging from 0.4 and $0.5 \mathrm{~g}$ biomass per $\mathrm{g}$ of sugar [18].

It is important to mention that it is difficult to compare biomass yields and productivity values for SCP production since they are strongly dependent on culture medium composition, the type of yeast and environmental conditions, such as incubation temperature, medium $\mathrm{pH}$, dissolved oxygen, aeration rate and fermentation mode [4]. However, it is still possible to compare the efficiency of the $25 \mathrm{~L}$ experiment with $W$. anomalus with results obtained for well-known SCP yeasts such as $C$. jadinii (anamorph name $C$. utilis). Bajpai et al. [23] reached a $Q_{x} 0.76 \mathrm{~g} / \mathrm{L} / \mathrm{h}$, i.e., five times lower than in our study (3.92 $\mathrm{g} / \mathrm{L} / \mathrm{h})$, for repeated fed-batch fermentations of $C$. utilis using the same ratio for the withdrawal and addition of medium $\left(V_{\text {out }} / V_{f}=0.75\right)$ but with a longer cycle time of $24 \mathrm{~h}$. Lee et al. [31] achieved biomass yields and productivities of $0.67 \mathrm{~g} / \mathrm{g}$ and $0.24 \mathrm{~g} / \mathrm{L} * \mathrm{~h}$ for batch fermentations, $0.51 \mathrm{~g} / \mathrm{g}$ and $1.95 \mathrm{~g} / \mathrm{L}^{*} \mathrm{~h}$ for fed-batch fermentations, and $0.36 \mathrm{~g} / \mathrm{g}$ and $2.15 \mathrm{~g} / \mathrm{L} * \mathrm{~h}$ for continuous fermentations, using C.utilis. Gao et al. [35] produced single-cell protein (SCP) from soy molasses using $C$. tropicalis and obtained maximum cell densities and protein concentrations of $10.83 \mathrm{~g} / \mathrm{L}$ and $6.11 \mathrm{~g} / \mathrm{L}$ in a $10 \mathrm{~L}$ bioreactor, using batch fermentation. Overall, comparing the yields and productivity values from the literature with the values presented in Table 5, it can be concluded that it was possible to effectively produce a reasonable amount of protein-rich yeast in the form of $W$. anomalus, using a medium composed of spruce-derived components (BALI ${ }^{\mathrm{TM}}$ hydrolysates), poultry by-products and urea.

\section{Amino acid composition}

The amino acid compositions of W.anomalus harvested during the $25 \mathrm{~L}$ fermentation, and of fish meal and soybean meal are presented in Table 6. Microorganisms to be used as feed ingredients would need a beneficial amino-acid profile, with 


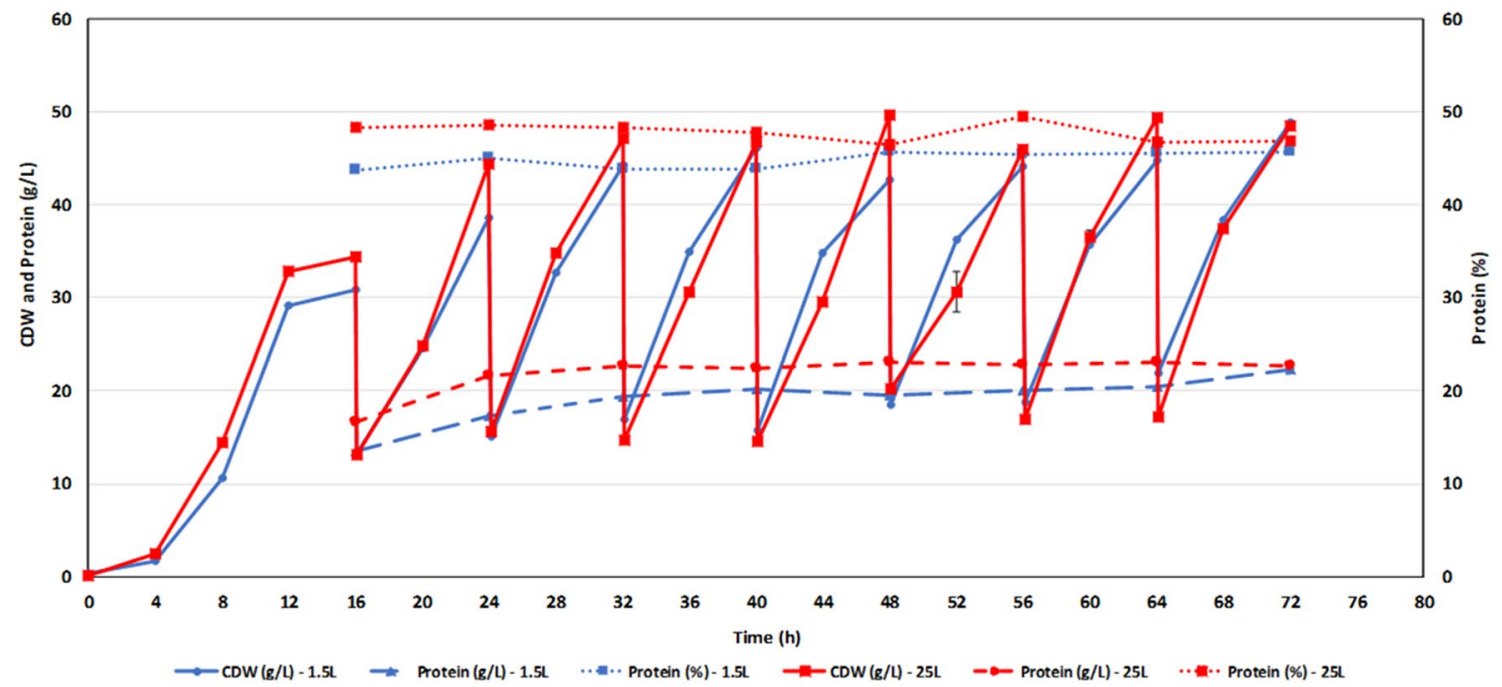

Fig. 3 Data for the $1.5 \mathrm{~L}$ and $25 \mathrm{~L}$ repeated fed-batch fermentations of $W$. anomalus grown on a medium containing an 80:20 mixture of poultry hydrolysate and urea as nitrogen source and BALI ${ }^{\mathrm{TM}}$ hydrolysate as sugar source. The $V_{\text {out }} / V_{f}$ was 0.75 , every $8 \mathrm{~h}$, and starting at $16 \mathrm{~h}$

Table 5 Growth characteristics for a $25 \mathrm{~L}$ repeated fed-batch fermentation of W. anomalus grown on BALI ${ }^{\mathrm{TM}}$ hydrolysate and an 80:20 mixture of poultry hydrolysate and urea

\section{W. anomalus}

Poultry hydrolysate $80 \%+$ UREA $20 \%$

Increase in $\mathrm{CDW}(\mathrm{g} / \mathrm{L})^{\mathrm{a}}$

Protein $(\%)$

Increase in protein $(\mathrm{g} / \mathrm{L})^{\mathrm{a}}$

Unconsumed glucose $(\mathrm{g} / \mathrm{L})$

$Y_{\mathrm{X} / \text { glucose }}^{\mathrm{b}}$

$Y_{\mathrm{X} / \text { sugars }}^{\mathrm{c}}$

$Y_{\mathrm{p} / \text { glucose }}^{\mathrm{b}}$

$Y_{\mathrm{p} / \text { sugars }}^{\mathrm{c}}$

$Q_{x}^{\mathrm{d}}$

$Q_{p}^{\mathrm{e}}$

$31.39 \pm 2.77$
$47.76 \pm 1.13$
$14.97 \pm 1.07$
$0.08 \pm 0.01$
0.66
0.50
0.31
0.24
3.92
1.87

The $V_{\text {out }} / V_{f}$ was 0.75 , every $8 \mathrm{~h}$, starting at $16 \mathrm{~h}$. The data shown are average values for the samples taken at $24 \mathrm{~h}$ and at the end of the subsequent six repeated batches (32-72 h). The nitrogen concentration in the medium was $5.86 \mathrm{~g} / \mathrm{L}$, whereas the glucose concentration was approximately $50 \mathrm{~g} / \mathrm{L}$ (the actual glucose concentrations were measured by HPLC at each sampling point and right after each harvest/ refill procedure, and these measurements were used for the calculations). Figure 3 and Supplementary Figure S6 provide the actual values of the parameters during the course of the fermentation

${ }^{a}$ Increase over the $8 \mathrm{~h}$ growth period following each harvest/refill procedure

${ }^{b}$ Yield of cell biomass $(\mathrm{X})$ or protein $(\mathrm{P})$ per consumed glucose

${ }^{\mathrm{c}}$ Yield of cell biomass $(\mathrm{X})$ or protein $(\mathrm{P})$ per total added sugar

${ }^{\mathrm{d}}$ Cell biomass productivity in $\mathrm{g} / \mathrm{L} / \mathrm{h}$

${ }^{\text {e}}$ Protein productivity in $\mathrm{g} / \mathrm{L} / \mathrm{h}$ particular attention to the nutritionally important amino acid methionine (Met), cysteine (Cys), lysine (Lys) and arginine (Arg) [36]. The data show that the amino acid composition of $W$. anomalus produced using $80 \%$ poultry hydrolysate and $20 \%$ urea with BALI ${ }^{\mathrm{TM}}$ sugar is similar to that of fishmeal and soybean meal, except for sulfur-containing amino acids such as methionine (Met) and cysteine (Cys). Low levels of sulfur-containing amino acids are common for yeast and bacterial biomasses [12] and normally restrict their use as the sole protein source in feed [37]. The data also show that the amino acid composition for $W$. anomalus is similar to the amino acid composition of the well-known feed ingredient C. jadinii grown on lignocellulosic substrates [27, 32, 38].

\section{Effects of different disruptive methods on $W$. anomalus}

W. anomalus has not been used in SCP production and little is known about how this yeast responds to downstream processing processes that are commonly in refining of SCP. To obtain some first insight into this issue, $W$. anomalus cells from the $25 \mathrm{~L}$ fermentation were subjected to varying potential processing steps. Cells from different harvesting points during the $25 \mathrm{~L}$ fermentation (16, 24, 32, 40, 48, 56, 64 and $72 \mathrm{~h}$ ) were pooled and subjected to separation using a continuous two-phase separator, resulting in a yeast cell paste with a dry weight of $15 \%(\mathrm{w} / \mathrm{v})$. After washing the cells, as described in the Materials and Methods section, they were subjected to varying disruptive methods followed by analysis of effects of on cell morphology using SEM. The SEM 
Table 6 Amino acid composition of W. anomalus obtained after repeated fed-batch fermentation on a medium containing an 80:20 mixture of poultry hydrolysate and urea as nitrogen source, and $\mathrm{BALI}^{\mathrm{TM}}$ sugar

\begin{tabular}{lllc}
\hline Amino acids & W. anomalus & Fish meal $^{\mathrm{b}}$ & Soybean meal $^{\mathrm{c}}$ \\
\hline EAAs $^{\mathrm{a}}$ & & & \\
Met, M & $3.27 \pm 0.07$ & 16.1 & 7.7 \\
Thr, T & $18.91 \pm 0.05$ & 25.4 & 20.2 \\
Val, V & $19.52 \pm 0.13$ & 26.4 & 24.1 \\
Ile, I & $18.41 \pm 0.13$ & 23.7 & 23.1 \\
Leu, L & $28.96 \pm 0.05$ & 42.0 & 39.0 \\
His, H & $11.19 \pm 0.18$ & 11.8 & 13.5 \\
Lys, K & $30.61 \pm 0.23$ & 45.5 & 32.3 \\
Ala, A & $24.11 \pm 0.18$ & 32.6 & 22.4 \\
Phe, F & $16.33 \pm 0.06$ & 22.0 & 26.5 \\
Trp, W & $5.20 \pm 0.22$ & 6.9 & 6.8 \\
NEAAs & & & \\
Asp, D & $40.51 \pm 0.15$ & 54.7 & 59.5 \\
Ser, S & $20.19 \pm 0.04$ & 25.3 & 25.8 \\
Glu, E & $76.50 \pm 0.48$ & 83.9 & 92.1 \\
Pro, P & $17.67 \pm 0.58$ & 23.1 & 24.1 \\
Gly, G & $22.18 \pm 0.08$ & 30.8 & 21.6 \\
Tyr, Y & $11.20 \pm 0.01$ & 15.2 & 14.7 \\
Arg, R & $25.71 \pm 0.04$ & 35.3 & 37.4 \\
Cys, C & $3.27 \pm 0.07$ & 5.7 & 6.9 \\
SUM AA & 395.8 & 526.4 & 497.8 \\
\hline
\end{tabular}

Values are mean $\pm \mathrm{SD}(n=2)$. EAAs essential amino acids, NEAAs non-essential amino acids

${ }^{\text {a }}$ All values are in $\mathrm{g} / \mathrm{kg}$ of dry matter

${ }^{\mathrm{b}}$ The content of amino acids in fish meal (except tryptophan) was taken from Hansen et al. [46]; the value for tryptophan comes from Skrede et al. [47]

${ }^{\mathrm{c}}$ The content of amino acids in soybean meal was taken from Sriperm et al. [48]

images of the autolyzed cells (Fig. 4b) did not differ much from the images of the untreated cells (Fig. 4a), while loss of cell integrity and liberation of internal contents were clearly visible in the pictures of homogenized cells (Fig. 4c). The SEM images also show a clear disruptive effect provoked by the use of the enzyme preparation Glucanex (Fig. 4d). These results indicate that several methods can be applied to disrupt the W. anomalus cells, which presumably would affect yeast digestibility. Such effects will be investigated in a follow-up study.

\section{Possible industrial applications as fish feed}

The three major feed companies in Norway jointly used 1.63 million tons of ingredients for production of fish feed in 2012 [39]. These ingredients are mainly of plant and marine origin, which combined yield a feed protein content of approximately 50\% (815,000 tons) [40]. If the SCP process developed in this study was to replace $10 \%$ of fish feed protein (81,500 tons), a total fermentation volume of approximately $5000 \mathrm{~m}^{3}$ would be needed, based on the results from the large-scale fermentation (protein productivity of $1.87 \mathrm{~g} / \mathrm{L} / \mathrm{h}$ or 0.016 tons/L/year). The commercial yeast producer Lallemand Inc. uses bioreactors with volumes of 100-300 $\mathrm{m}^{3}$ for production of baker's yeast [41]. If bioreactors of $300 \mathrm{~m}^{3}$ (assuming a working volume of $200 \mathrm{~m}^{3}$ ) were used for production of SCP, a yearly production of 81,500 tons of fish protein would require 25 of such vessels (see Supplementary Table S3 for the numbers on which this and the subsequent calculations are based).

Regarding the raw materials, production of 81,500 tons of protein would annually require approximately 0.33 million tons of protein from poultry hydrolysate, 12,550 tons of urea and 220,000 tons of cellulose, which translates to 0.96 million tons of wet spruce [42, 43], which would amount to $11.3 \%$ of the total annual spruce harvest in Norway [44]. Of note, while the poultry hydrolysate:urea ratio was somewhat optimized in this study, we did not look into how to minimize the amount of the poultry hydrolysate-urea mixtures used. Thus, some further improvements in process economy should be feasible.

\section{Conclusions}

In conclusion, this study demonstrates that $W$. anomalus is better suited than and $B$. adeninivorans and the well-established $C$. jadinnii to produce microbial protein in a medium composed of a mixture of organic and inorganic nitrogen sources and spruce-derived sugars in a semi-continues mode. The protein content of the yeast biomass produced in the $42 \mathrm{~L}$ fermenter was high (around $50 \mathrm{w} / \mathrm{w} \%$ ), and the amino-acid profile of $W$. anomalus was reasonable, albeit with the deficit in sulfur-containing amino acids, which is common for yeast and bacterial biomasses. The inclusion of $W$. anomalus has shown promising results in feeding experiments with rainbow trout [45]. However, further feeding experiments with $W$. anomalus as SCP in diets for animals and fish are needed to establish the full potential of the protein-rich $W$. anomalus cells produced by the protocols described in this study. It will also be important to investigate how different downstream processing routes, including cell disruptive methods, affect protein digestibility and nutritional value in animals and fish.

Additional research efforts may also be needed to further optimize and develop a more economically viable yeast production process based on industrial side-streams as substrates, in combination with cheap inorganic nitrogen sources. The poultry by-product hydrolysates used in this study are probably not best suited for SCP production, 

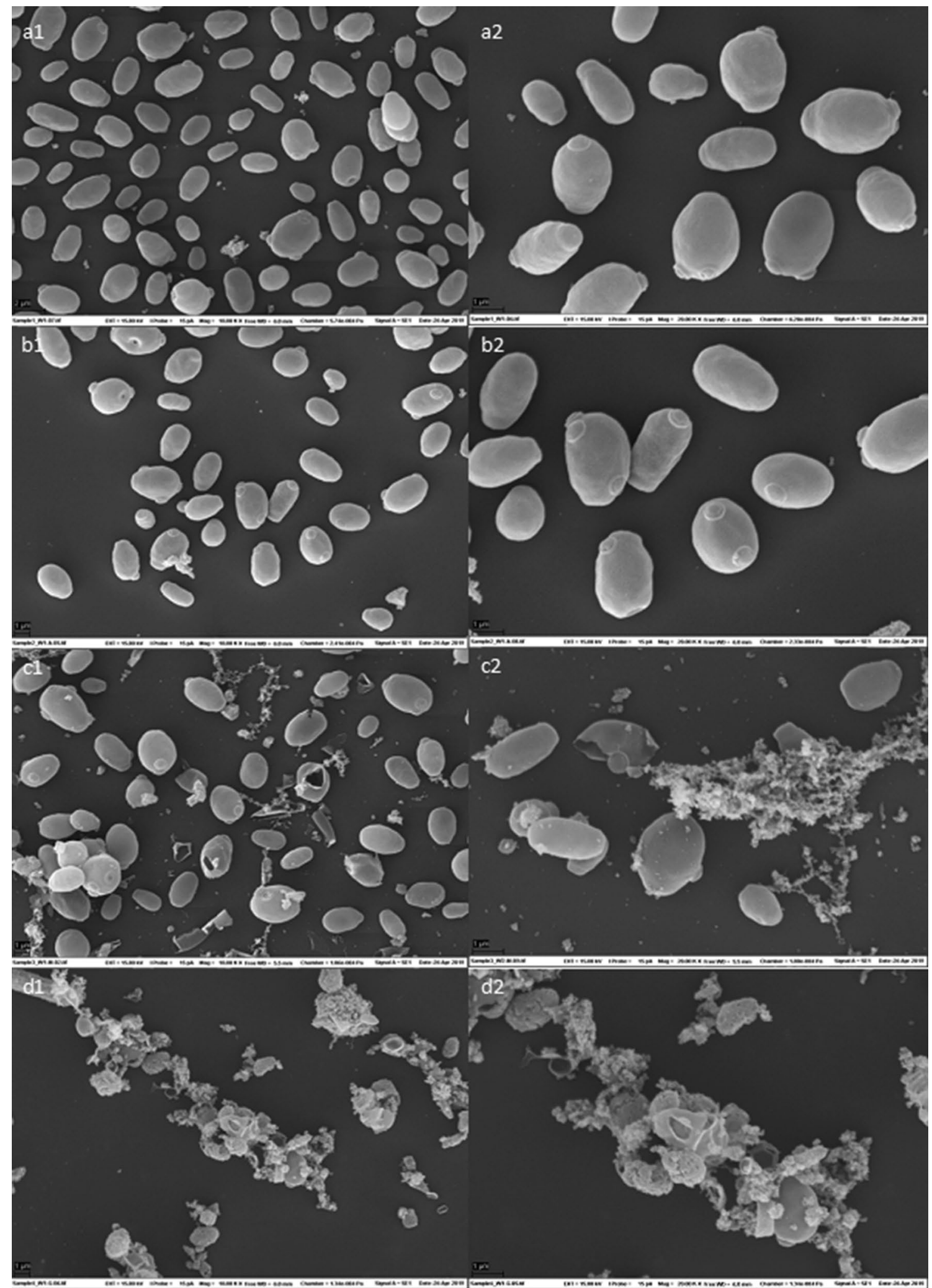

Fig. 4 SEM images of $W$. anomalus cells after different potentially disruptive treatments. a Untreated yeast; b autolysis; c homogenization using a microfluidizer; $\mathbf{d}$ enzymatic hydrolysis using Glucanex.
For each treatment, two magnifications are shown, 10,000 (panels labeled 1) and 20,000 (panels labeled 2) 
because they may find higher value applications in other markets, such as in food. Continuous fermentation modes may be worth further exploration, since these are also considered to be good strategies for microbial biomass production [18].

Acknowledgements We thank Norilia AS, Nortura Hærland, and BIOCO AS for providing the protein-rich poultry hydrolysate, Borregaard AS for providing the lignocellulosic hydrolysate (BALI ${ }^{\mathrm{TM}}$ ), and Yara International ASA for providing urea. A special thanks to the contact persons from our industrial partners: Marije Oostindjer, Eirik Pallin, Oskar Bengtsson and Wolfram Franke. We would also like to thank Mari Brusletten, Line Degn Hansen and Lars Fredrik Moen for assistance in some phases of this study. We would like to acknowledge Hilde Raanaas Kolstad and Lene Cecilie Hermansen at the Imaging Centre of the Faculty of Biosciences at NMBU for help producing the scanning electron microscopy images. This work was supported by the Research Council of Norway through grants 237841 (Foods of Norway) and 270038 (NorBioLab).

\section{Compliance with ethical standards}

Conflict of interest The authors declare that they have no conflict of interest.

Ethical approval This article does not contain any studies with human participants performed by any of the authors.

Human and animal rights The research did not involve human participants and/or animals.

Open Access This article is licensed under a Creative Commons Attribution 4.0 International License, which permits use, sharing, adaptation, distribution and reproduction in any medium or format, as long as you give appropriate credit to the original author(s) and the source, provide a link to the Creative Commons licence, and indicate if changes were made. The images or other third party material in this article are included in the article's Creative Commons licence, unless indicated otherwise in a credit line to the material. If material is not included in the article's Creative Commons licence and your intended use is not permitted by statutory regulation or exceeds the permitted use, you will need to obtain permission directly from the copyright holder. To view a copy of this licence, visit http://creativecommons.org/licenses/by/4.0/.

\section{References}

1. Anupama Ravindra P (2000) Value-added food: single cell protein. Biotechnol Adv 18:459-479. https://doi.org/10.1016/S0734 -9750(00)00045-8

2. Aspevik T, Oterhals A, Rønning SB, Altintzoglou T, Wubshet SG, Gildberg A, Afseth NK, Whitaker RD, Lindberg D (2017) Valorization of proteins from co- and by-products from the fish and meat industry. Top Curr Chem 374:53. https://doi.org/10.1007/ s41061-017-0143-6

3. Spalvins K, Ivanovs K, Blumberga D (2018) Single cell protein production from waste biomass: review of various agricultural by-products. Agron Res 16:1493-1508. https://doi.org/10.15159 IAR.18.129

4. Mondal AK, Sengupta S, Bhowal J, Bhattacharya DK (2012) Utilization of fruit wastes producing single cell protein. Int J Sci Environ Technol 1:430-438
5. Nasseri AT, Rasoul-Amini S, Morowvat MH, Ghasemi Y (2011) Single cell protein: production and process. Am J Food Technol. https://doi.org/10.3923/ajft.2011.103.116

6. Miller BM, Litsky W (1976) Single cell protein in industrial microbiology, 1st edn. McGrow-Hill Book Co, New York

7. Ritala A, Häkkinen ST, Toivari M, Wiebe MG (2017) Single cell protein-state-of-the-art, industrial landscape and patents 20012016. Front Microbiol 8:1-18. https://doi.org/10.3389/fmicb .2017 .02009

8. Pacheco MT (1997) Composition and nutritive value of yeast biomass and yeast protein concentrates. J Nutr Sci Vitam 43:601612. https://doi.org/10.3177/jnsv.43.601

9. Nguyen TH, Fleet GH, Rogers PL (1998) Composition of the cell walls of several yeast species. Appl Microbiol Biotechnol 50:206-212. https://doi.org/10.1007/s002530051278

10. Rakowska R, Sadowska A, Dybkowska E, Świderski F (2017) Spent yeasts as natural source of functional food additives. Rocz Panstw Zakl Hig 68:115-121

11. Navarrete P, Tovar-ramírez D (2014) Use of yeasts as probiotics in fish aquaculture. In: Hernandez-vergara M, Perez-Rostro C (eds) Sustainable aquaculture techniques, 1st edn. IntechOpen Limited, London

12. Bajpai P (2017) Single cell protein production from lignocellulosic biomass, 1st edn. Springer, Jaipur

13. Lapeña D, Vuoristo KS, Kosa G, Horn SJ, Eijsink VGH (2018) Comparative assessment of enzymatic hydrolysis for valorization of different protein-rich industrial byproducts. J Agric Food Chem 66:9738-9749. https://doi.org/10.1021/acs.jafc.8b02444

14. Anigbogu VC, Dietz ML, Syty A (1983) Determination of ammonium, nitrate, and urea nitrogen in fertilizer by gas-phase molecular absorption spectrometry. Anal Chem 55:535-539. https://doi. org/10.1021/ac00254a027

15. Choudary PV, Rao GR (1984) Molecular analysis of inorganic nitrogen assimilation in yeasts. Arch Microbiol 138:183-186. https://doi.org/10.1007/BF00402116

16. Fiechter A, Kappeli O, Meussdoerffer F (1987) Batch and continuous culture. In: Rose AH, Harrison JS (eds) The yeasts, 2nd edn. Academic press, London, pp 99-129

17. Yoshida F, Yamane T (1973) Fed-batch hydrocarbon fermentation with colloidal emulsion feed. Biotechnol Bioeng 15:257-270. https://doi.org/10.1002/bit.260150204

18. Ugalde UO, Castrillo JI (2002) Single cell proteins from fungi and yeasts. Appl Mycol Biotechnol 2:123-149. https://doi. org/10.1016/S1874-5334(02)80008-9

19. Hospodka J (1966) Industrial application of continuous fermentation. In: Malek I, Fencl Z (eds) Theoretical and methodological basis of continuous culture of microorganisms. Academic Press, New York, pp 493-645

20. Rose AH (1979) Microbial biomass. In: Rose AH (ed) Economic microbiology. Academic press, London

21. Ward OP (1992) Biomass production. In: Ward OP (ed) Fermentation technology. Willey, Chichester, p 91

22. Pirt SJ (1974) The theory of fed batch culture with reference to the penicillin fermentation. J Appl Chem Biotechnol 24:415-424. https://doi.org/10.1002/jctb.2720240706

23. Bajpai P, Bajpai PK (1988) Repeated fed batch fermentation for single cell protein production from prehydrolysate of a pulp mill. Enzyme Microb Technol 10:5-8. https://doi.org/10.1016/01410229(88)90128-7

24. Chylenski P, Petrović DM, Müller G, Dahlström M, Bengtsson O, Lersch M, Siika M, Horn SJ, Eijsink VGH (2017) Enzymatic degradation of sulfite-pulped softwoods and the role of LPMOs. Biotechnol Biofuels 10:1-13. https://doi.org/10.1186/s1306 8-017-0862-5 
25. Rødsrud G, Lersch M, Sjöde A (2012) History and future of world's most advanced biorefinery in operation. Biomass Bioenerg 46:46-59. https://doi.org/10.1016/j.biombioe.2012.03.028

26. Wu J, Hu J, Zhao S, He M, Hu G, Ge X, Peng N (2018) Singlecell protein and xylitol production by a novel yeast strain Candida intermedia FL023 from lignocellulosic hydrolysates and xylose. Appl Biochem Biotechnol 185:163-178. https://doi.org/10.1007/ s12010-017-2644-8

27. Rajoka MI, Kiani MAT, Khan S, Awan MS, Hashmi A (2004) Production of single cell protein from rice polishings using Candida utilis. World J Microbiol Biotechnol 3:297-301. https://doi. org/10.1023/B:WIBI.0000023845.96123.dd

28. Middelhoven WJ, de Jong IM, de Winter M (1991) Arxula adeninivorans, a yeast assimilating many nitrogenous and aromatic compounds. Antonie Van Leeuwenhoek 59:129-137. https://doi. org/10.1016/j.msec.2014.04.068

29. Batistote M, Helena Da Cruz S, Ernandes JR (2006) Altered patterns of maltose and glucose fermentation by brewing and wine yeasts influenced by the complexity of nitrogen source. J Inst Brew 112:84-91. https://doi.org/10.1002/j.2050-0416.2006.tb002 35. $\mathrm{x}$

30. Zeng A-P, Sun J (2010) Continuous culture. In: Baltz RH, Demain AL, Davies JE (eds) Manual of industrial microbiology and biotechnology, 3rd edn. ASM Press, Washington DC

31. Lee B, Kim JK (2001) Production of Candida utilis biomass on molasses in different culture types. Aquac Eng 25:111-124. https ://doi.org/10.1016/S0144-8609(01)00075-9

32. Sharma S, Hansen LD, Hansen JO, Mydland LT, Horn SJ, Øverland M, Eijsink VGH, Vuoristo KS (2018) Microbial protein produced from brown seaweed and spruce wood as a feed ingredient. J Agric Food Chem 66:8328-8335. https://doi.org/10.1021/acs. jafc. $8 \mathrm{~b} 01835$

33. Malak A, Baronian K, Kunze G (2016) Blastobotrys (Arxula) adeninivorans: a promising alternative yeast for biotechnology and basic research. Yeast 33:535-547. https://doi.org/10.1002/ yea. 3180

34. Roon RJ, Levenberg B (1972) Urea amidolyase. J Biol Chem 247:4107-4113

35. Gao Y, Li D, Liu Y (2012) Production of single cell protein from soy molasses using Candida tropicalis. Ann Microbiol 62:11651172. https://doi.org/10.1007/s13213-011-0356-9

36. Vasey RB, Powell KA (1984) Single-cell protein. Biotechnol Genet Eng Rev 2:285-311. https://doi.org/10.1080/02648 725.1984.10647802

37. Oliva-Teles A, Goncalves P (2001) Partial replacement of fishmeal by brewers yeast (Sacharomyces cerevisiae) in diets for sea bass (Dicentrarchus labrax) juveniles. Aquaculture 202:269-278. https ://doi.org/10.1016/S0044-8486(01)00777-3
38. Yunus F, Nadeem M, Rashid F (2015) Single-cell protein production through microbial conversion of lignocellulosic residue (wheat bran) for animal feed. Inst Brew Distill 121:553-557. https ://doi.org/10.1002/jib.251

39. Ytrestøyl T, Aas TS, Åsgård T (2015) Utilisation of feed resources in production of Atlantic salmon (Salmo salar) in Norway. Aquaculture 448:365-374. https://doi.org/10.1016/j.aquacultur e.2015.06.023

40. FAO (2019) FAO. Atlantic salmon-Nutritional requirements. In: Food Agric. Organ. United nations. http://www.fao.org/fishery/ affris/species-profiles/atlantic-salmon/nutritional-requirements/ en/. Accessed 20 Aug 2019

41. Inc Lallemand (2018) Bakers yeast production and characteristics. Lallemand Bak Updat 3:4-5

42. Bertaud F, Holmbom B (2004) Chemical composition of earlywood and latewood in Norway spruce heartwood, sapwood and transition zone wood. Wood Sci Technol 38:245-256. https://doi. org/10.1007/s00226-004-0241-9

43. Laurila J, Lauhanen R (2010) Moisture content of norway spruce stump wood at clear cutting areas and roadside storage sites. Silva Fenn 44:427-434. https://doi.org/10.14214/sf.140

44. (2019) Landbruksdirektoratet. Tømmeravvirkning og -priser. https ://www.landbruksdirektoratet.no/no/statistikk/skogbruk/tomme ravvirkning. Accessed 19 May 2019

45. Huyben D, Nyman A, Vidaković A, Passoth V, Moccia R, Kiessling A, Dicksved J, Lundh T (2017) Effects of dietary inclusion of the yeasts Saccharomyces cerevisiae and Wickerhamomyces anomalus on gut microbiota of rainbow trout. Aquaculture 473:528-537. https://doi.org/10.1016/j.aquaculture.2017.03.024

46. Hansen JØ, Penn M, Øverland M, Shearer KD, Krogdahl A, Mydland LT, Storebakken T (2010) High inclusion of partially deshelled and whole krill meals in diets for Atlantic salmon (Salmo salar). Aquaculture 310:164-172. https://doi. org/10.1016/j.aquaculture.2010.10.003

47. Skrede A, Berge G, Storebakken T, Herstad O, Aarstad KG, Sundstøl F (1998) Digestibility of bacterial protein grown on natural gas in mink, pigs, chicken and Atlantic salmon. Anim Feed Sci Technol 76:103-116. https://doi.org/10.1016/S0377 -8401(98)00208-9

48. Sriperm N, Pesti GM, Tillman PB (2011) Evaluation of the fixed nitrogen-to-protein $(\mathrm{N}: \mathrm{P})$ conversion factor $(6.25)$ versus ingredient specific N: P conversion factors in feedstuffs. J Sci Food Agric 91:1182-1186. https://doi.org/10.1002/jsfa.4292

Publisher's Note Springer Nature remains neutral with regard to jurisdictional claims in published maps and institutional affiliations. 